\title{
СЛЕДЫ ОГРАНИЧЕННОГО МНОЖЕСТВЕННОГО ЧИСЛА В СТРУКТУРЕ СУЩЕСТВИТЕЛЬНЫХ РУТУЛЬСКОГО ЯЗЫКА
}

\section{TRACES OF THE RESTRICTED PLURAL IN THE NOUN STRUCTURE OF THE RUTUL LANGUAGE}

\section{Ibragimova}

Summary: The article formulates the general provisions resulting from the analysis of nouns with limited plural affixes in the dialects of the Rutul language in order to clarify the diachronic scenarios and the prospects for the development of the grammatical category of numbers in them. It is revealed that the absence in the speech of native speakers Rutul language nouns, as opposed to forms of limited and unlimited plural simultaneous phase and parallel operation of complicated and simplified system of declension of nouns, some plural verify the simplification process once complex numbers in the dialects of the studied language.

Keywords: Rutul language, plural, limited plural, Borch-Khnov dialect, Ihrek dialect, Muhrek dialect, Shinaz dialect.
Ибрагимова Мариза Оглановна

Д.филол.н., доцент, в.н.С., Институт языка, литературы и искусства Дагестанского федерального исследовательского чентра РАН (2. Махачкала), mariza71@mail.ru

Аннотация: В статье сформулированы общие положения, явившиеся результатом анализа имен существительных с маркерами ограниченного множественного числа в диалектах рутульского языка с целью выяснения диахронических сценариев и перспектив развития в них грамматической категории числа. Выявлено, что отсутствие в речи носителей рутульского языка существительных, противопоставленных формами ограниченного и неограниченного множественного числа, на синхронном этапе и параллельное функционирование осложненной и упрощенной систем склонения некоторых существительных множественного числа верифицирует процесс упрощения некогда сложной категории числа в диалектах исследуемого языка.

Ключевые слова: рутульский язык, множественное число, ограниченное множественное число, борчинско-хновский диалект, ихрекский диалект, мюхрекский диалект, шиназский диалект.
$\Pi$ ри анализе существительных множественного числа в рутульском языке, относящемся к лезгинской группе нахско-дагестанской языковой семьи, обращает на себя внимание ряд лексем ограниченного множественного числа, обозначающих, за редким исключением, парные предметы и образующихся путем прибавления сложных аффиксов: -аб-ыр: убр-аб-ыр «уши», хыл-аб-ыр «руки», гъил-аб-ыр «ноги», m/ил-аб-ыр «пальцы», ул-аб-ыр «глаза», mluml-aб-ыр «груди», кыл-аб-

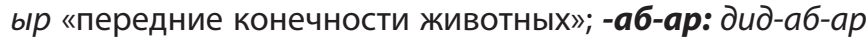
«отцы, отец и его родственники», нин-аб-ар «матери, матери и их родственники».

Посредством присоединения аффикса -аб-ыр образуется форма мн. числа кьул-аб-ыр «головы» от лексемы кьул «голова», не имеющей семантику парности. В форме плюралиса нескольких лексем, не имеющих семантику парности, также выделяются сложные аффиксы -уб-ыр, -ыб-ыр: кьул «доска» - кьул-уб-ыр, mlул «прут» - mlул-убыр, дур «имя» - дурубыр, гыр «миска» - гыр-ыбыр.

Г.Х. Ибрагимов связывает наличие этого сложного форманта в структуре парных существительных с имевшим место в языке этимологически ограниченным множественным числом [1974, с. 85]. По словам исследователя, «Структурный анализ указанных лексем позволяет полагать, что -аб- в форме мн. числа этих лексем является не фонетическим наращением, а самостоятельным формантом, когда-то имевшим определенную морфо- логическую функцию... В плане статики -аб- в структуре форманта множественности (-аб-ыр < аб-быр) является избыточным... Удовлетворительное объяснение приро-

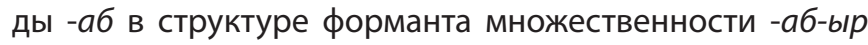
содержится в семантике лексем. Все эти имена (ул «глаз», хыл «рука», гъил «нога», убур «ухо», mluml «сосок/грудь») являются названиями парных частей тела, что позволяет этимологически квалифицировать этот -аб- как формант двойственного (или ограниченного мн.) числа» [Ибрагимов, 2004, С. 52-53].

В мухадском диалекте сохранились застывшие формы ограниченного множественного числа в устойчивых сочетаниях, в благопожеланиях и проклятиях:

хыл-аб ле-ø-шун

рука-IN.PL <III, IV.PL> взять-MASD

«сделать омовение»

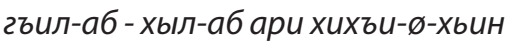

рука-IN.PL - нога -IN.PL внутрь-ADV <III, IV.PL> вложить-MASD

«собираться»

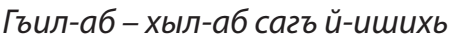

рука-IN.PL - нога -IN.PL здоровы III,IV.PL-пусть будут-ІMP

ноги-руки здоровы будут пусть (благопожелание)

ул-аб-аа быркьаl й-ишихь

глаз-IN.PL-IN.ES/IN.LAT слеп І-пусть будет-IMP

пусть ослепнет (проклятие) 
убр-аб хуІляхды йимаьл

yxo-IN.PL длинный осёл

об упрямом человеке

При этом проклятие с лексемой убрабыр «уши», имеющей форму ограниченного множественного числа, убрымаа быше йишихь! (букв. «из ушей оглохнет пусть») используется в рутульском языке в усеченной форме, без показателя ограниченного мн. числа. В бытовой речи возможно употребление обоих вариантов:

убры-м-а баьмбаьк ихьяъ

ухо-OBL.PL-IN.ES/IN.LAT вата IV-вложи-IMP

в уши вату положи

убр-аб-ыр-м-а баьмбаьк ихьяь

ухо-IN.PL-PL-OBL.PL-IN.ES/IN.LAT вата IV-вложи-IMP в уши вату положи

В контексте описания семантики ограниченного множественного числа интересна лексема эгбыр «подковы», имеющая параллельные формы косвенной основы во мн. числе: эгмыклаа «из-под подков» (форма контэлатива неограниченного мн. числа) // эгелмыклаа (форма контэлатива ограниченного мн. числа, употребляемая при характеристике всех четырех подков на копытах одной лошади).

Къамчиеклаа гивирчере,

плеть-CONT.EL <III>уворачиваясь-CONV

От плети уворачиваясь,

Эгелмыклаа цІай кийчере,

подкова-OBL-OBL.PL-CONT.ELoгонь $<\mathrm{IV}>$ отскакивая - CONV

Из-под подков искрами сверкая,

ЙикІ гьавыдаа хьуъ лийчере,

сердце-ABS воздух-AD.EL вперед-ADV <IV>летяCONV

Сердцем по небу (воздуху) летя,

Сувшур а йигит гъад йиван.

<III>мчась-CONV есть джигит-ABS находящийсяPART конь-ABS

Мчится джигита несущий конь. (Бийизат Рамазанова)

С. М. Махмудова считает формы рутульского языка хылаб «руки», гъилаб «ноги», убраб «уши», нинаб «матери», дидаб «отцы», тиллаб «пальцы», улаб «глаза» архаичными формами множественного числа, которые затем присоединили агглютинирующие суффиксы [2001, с. 26]. Относительно структуры форм плюралиса исследователь отмечает, что «Суффикс -бар с тематическим - $а$ удалось зафиксировать в двух случаях: нин 'мать' - нина-бар, дид 'отец' - дид-а-бар» [Махмудова, 2001, с. 19]. В отличие от С. М. Махмудовой, в формах нинабар «матери», дидабар «отцы» мы выделяем инфиксальный маркер плюралиса -аб- и постфиксальный маркер -ар. Подобное структурирование верифицируется наличием в рутульском языке устойчивых выражений, сохранивших формы ограниченного множественного числа с инфиксальным показателем -аб-: убраб ху1ляхды йымаьл «осел с длинными ушами» (об упрямом человеке), хылаб лешун «сделать омовение» (букв. руки взять) и др.

Наличие подобных форм зафиксировано и в других диалектах рутульского языка. Так, противопоставление двойственного и множественного чисел, по свидетельству Г.Х. Ибрагимова, сохраняется в ихрекском диалекте рутульского языка: хыл-аб - хыл-аб-ыр «руки» [1978, с. 201].

К.Э. Джамалов и С.А. Семедов отмечают, что в ихрекском диалекте «названия некоторых парных предметов образуют множественное число посредством сложного форманта -аб-ыр, например: (глаз) ул - ул-аб-ыр, (рука) хыл-хыл-аб-ыр, (нога) гъил - гъил-аб-ыр, (ухо) убур - убраб-ыр» [2006, с. 428].

В шиназском диалекте рутульского языка также имеет место параллельное употребление форм множественного и ограниченного множественного числа:

Гьиширы зы бырджбыр ахтармиш гьаъара,

Чыкара улабаа саъ нагъв савъад, зар. (Шиназ Эзерчи). Осталось мне долги считать,

Поневоле из глаз слезы проливая, деньги.

Специфичен этот сложный аффикс множественности в хновском говоре - в нем отсутствует финальный - $p$ : хыл-

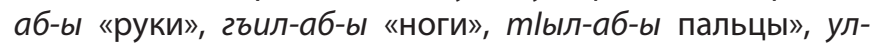
аб-ы «глаза», кыл-аб-ы «передние конечности животных».

Различия наблюдаются и при склонении описанных выше существительных:

\section{Мухадский диалект}

NOM - нин-аб-ар «матери» ул-аб-ыр «глаза»

ERG - нин-аб-а(р)-ш-еул-аб-ыр-м-ыра

GEN - нин-аб-а(р)-ш-ды у ул-аб-ыр-м-ыд

DAT - нин-аб-а(р)-ш-ис ул-аб-ыр-м-ыс

Парадигма склонения этих слов в хновском говоре демонстрирует структуру падежных форм, в которой в косвенных падежах отсутствует наращение - $a б$, что вместе с отсутствием финального - $p$ в номинативе и во всех остальных падежах существенно упрощает склонение существительных ограниченного множественного числа.

\section{Хновский говор \\ NOM - хыл-аб-ы «руки» у ул-аб-ы «глаза» \\ ERG - хыл-а-м-ыра ул-а-м-ыра \\ GEN - хыл-а-м-ыд ул-а-м-ыд \\ DAT - хыл-а-м-ыс $\quad$ ул-а-м-ыс и т.д.}

Улаб быркь гаъакьыр, mІылаб фадикluи, Бахт угълуукур, кlикlеul лошур дугъургъа (Курбанов Сакит)

букв. Глаза ослепив, пальцы прищемив,

Счастье отвергнув, трость взяв, ходят. 
Мы полагаем, что склонение этих слов в хновском говоре отражает перспективы, ожидающие склонение слов в ограниченном множественном числе в других ареальных единицах рутульского языка и в цахурском языке [Ибрагимова, 2020, с. 94]. Доказательством этому может послужить появление параллельных форм склонения (осложненной и упрощенной) существительного мн. числа убрабыр «уши» в мухадском диалекте:

\section{Мухадский диалект}

NOM - убр-аб-ыр «уши»

ERG - убр-аб-ыр-м-ыра убр-ы-м-ыра

GEN - убр-аб-ыр-м-ыд убр-ы-м-ыд

DAT - убр-аб-ыр-м-ыс убр-ы-м-ыс и т.д.

С. М. Махмудова считает, что в подобных словах «приспособление аффикса - $p$ - для передачи семантики множественности стало заключительной попыткой отразить семантику множественности» [2001, с. 26]. Возможно, исторически рутульский язык развивался по пути осложнения структур имен, но на современном этапе говорящие стремятся к упрощению словоформ.

М.Е. Алексеев предполагает такой сценарий развития, «когда старая форма множественного числа, вытесненная новой, приобретает значение единственного, в то время как исконная сингулярная основа утрачивается» [Алексеев, 2003, с. 178]. Подтверждением этой гипотезе могут служить приводимые им когнаты лексемы «седло» на лезгинских языках: лезг. пур-ар, таб. пupn-йup, агул. nylp-ap, рут. nan-pa [Там же, с. 179].

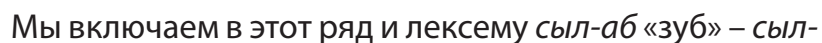
аб-ыр, полагая, что в рутульском языке современная сингулярная основа сыл-аб «зуб» содержит компонент -аб, характерный для слов ограниченного множественного числа (гъилаб «ноги», хылаб «руки»), сохранившихся в устойчивых выражениях, со временем форма ограниченного мн. числа стала восприниматься как сингулярная и к ней присоединяется аффикс множественности -быр. Когнаты из диалектов рутульского языка и род- ственных языков (ихр., мюхр. и шин. д. сыс; будух.: сил сил-имер// сил-имбер// сил-ибер, крыз. сил «зуб»-сил-им, цах. сили - сили-бы), имеющие односложную структуру, также служат доказательной базой.

Таким образом, в рутульском языке и его диалектах последовательно выявляются следы ограниченного множественного числа, формы которого образованы присоединением сложных аффиксов, первая часть которых отражает семантику ограниченного множественного числа, вторая - семантику неограниченного множественного числа.

Тот факт, что застывшие формы ограниченного множественного числа сохранились во всех диалектах в составе устойчивых сочетаний, благопожеланий, проклятий, позволяет говорить об активном функционировании этой категории на более глубоком хронологическом уровне. Отсутствие в речи носителей рутульского языка существительных в форме ограниченного мн. числа на синхронном этапе его развития и параллельное функционирование осложненной и упрощенной систем склонения существительных мн. числа верифицирует процесс упрощения некогда сложной категории числа в диалектах исследуемого языка.

\section{Список условных сокрашений}

ABS - абсолютив, ADV - наречие, AD.EL - адэлатив, CONT.EL - контэлатив, CONV - деепричастие, DAT - датив, GEN - генитив, ERG - эргатив, IMP - императив, INES/ INLAT - инэссив/инлатив, INF - инфинитив, IN.PL - инфиксальный показатель ограниченного множественного числа имен существительных, PL - показатель множественного числа, OBL.PL - детерминатив косвенной основы множественного числа, РАRT - причастие, I, II, III, IV - номер класса, агул. - агульский язык, будух. - будухский язык, ихр. - ихрекский диалект, крыз. - крызский язык, лезг. - лезгинский язык, мюхр. - мюхрекский диалект, рут - рутульский язык, таб. - табасаранский язык, шин. - шиназский диалект, цах. - цахурский язык.

\section{ЛИТЕРАТУРА}

1. Алексеев М.Е. Сравнительно-историческая морфология нахско-дагестанских языков. Категории имени. - М.: Academia, 2003. 264 с.

2. Джамалов К.Э., Семедов С.А. Краткий грамматический очерк рутульского языка.// Рутульско-русский словарь (ихрекский диалект). - М.: Экон-Информ, $2006.466 \mathrm{c}$.

3. Ибрагимов Г.Х. 0 многоформантности множественного числа имени существительного в восточно-кавказских языках (на материале рутульского, цахурского, крызского и будухского языков) // ВЯ, 1974.- № 3.

4. Ибрагимов Г.Х. Рутульский язык. - М.: Наука, 1978. 306 с.

5. Ибрагимов Г.Х. Рутульский язык. Синхрония и диахрония. Махачкала, 2004. 308 с.

6. Ибрагимова М.О. Категория падежа и морфология склонения в рутульском языке: диалектная стратификация. - Махачкала: АЛЕФ-ИЯЛИ ДНЦ РАН, 2019. 220 с.

7. Махмудова С.М. Морфология рутульского языка. - Москва, 2001. 256 с.

( ) Ибрагимова Мариза Оглановна (mariza71@mail.ru).

Журнал «Современная наука: актуальные проблемы теории и практики» 